\title{
A new species of Antillorena from Colombia (Araneae: Zodariidae: Lachesaninae)
}

\author{
Luis G. Quijano-Cuervo ${ }^{1,2}$ (1) \& Antonio D. Brescovit ${ }^{3}$
}

1. Grupo Biodiversidad del Caribe Colombiano, Facultad de Ciencias Básicas, Universidad del Atlántico, Colombia.
2. Instituto de Ecología (INECOL), Xalapa, Veracruz, México. (luisquijanocuervo@gmail.com)
3. Laboratório Especial de Coleções Zoológicas, Instituto Butantan, Av.VVital Brasil, 1500, Butantã, 05503-900 São Paulo, SP, Brazil. (antonio.brescovit@butantan.gov.br)

Received 9 May 2018

Accepted 17 October 2018

Published 29 November 2018

DOI 10.1590/1678-4766e2018039

ABSTRACT. The genus Antillorena Jocqué, 1991 is reported in Colombia for the first time and A. sanjacintensis sp. nov. is described for the north of the country. This new species is diagnosed with the type species Antillorena polli (Simon, 1887). A taxonomic key and a map with the distribution of all species of the genus are included.

KEYWORDS. Neotropical region, spiders, key.

RESUMEN. Una nueva especie de Antillorena de Colombia (Araneae: Zodariidae: Lachesaninae). El género Antillorena Jocqué, 1991 es reportado en Colombia por primera vez y A. sanjacintensis sp. nov. es descrita para el norte del país. Esta nueva especie se diagnostica con la especie tipo Antillorena polli (Simon, 1887). Se incluye una clave taxonómica y un mapa con la distribución de todas las especies del género.

PALABRAS CLAVE. Región Neotropical, arañas, clave.

Antillorena Jocqué 1991 is a genus with Neotropical distribution, which currently includes three valid species from the Lesser Antilles and Brazil (World SPIDER Catalog, 2018). According to Gertsch (1961) the species of this genus have cursorial habits and are characterized by building burrows lined with silk and closed with a wafer-type trapdoor. The first species of the genus was described for the Lesser Antilles under the name Storena pollii (Simon) (sic) in Hasselt (1887) (current spelling Storena polli; see World Spider Catalog, 2018). However, later Jocqué (1991) considered that this species was misplaced, proposing Antillorena Jocqué to include S. polli. Recently, BRESCOVIT \& RuIz (2011) described two new species of the genus, A. gaia and A. patapata, expanding distribution to South America. Antillorena is distinguished from other members of the family by the long and coiled embolus and conspicuous proximal tegular apophysis in the male palp, as well as, the very long copulatory ducts, with more than three turns surrounding the elongated spermathecae in the female epigynum (JoCQUÉ 1991; BRESCOVIT \& RuIZ 2011).

The aim of this study is to describe a new species from Bolivar and Atlántico Departments, northern Colombia, which represents the first record of the Antillorena in the country. In addition, an identification key and a distribution map of all currently known species in the genus are provide, along with supplementary documentation of $A$. polli.

\section{MATERIAL AND METHODS}

Specimens were preserved in $96 \%$ ethanol. Male palps were detached from the body and illustrated in ventral and retrolateral views. Female epigynum was dissected and immersed in $\mathrm{KOH} 10 \%$, in order to clarify soft tissue, to study internal structures. Measurements are expressed in millimeters and were preferentially taken in the left side of specimens. The photos were taken with a Leica MC170 HD camera attached to a Leica M125 stereoscope. Terminology and format of descriptions follow JOCQUÉ (1991). Spine notation follows Petrunkevitch (1925). Abbreviations: d, dorsal; $p$, prolateral; $r$, retrolateral; $v$, ventral; ALE, anterior lateral eye; AME, anterior median eye; PLE, posterior lateral eye; PME, posterior median eye; MOQ, median ocular quadrangle. The material examined was deposited in the Arachnological Collection of the Instituto de Ciencias Naturales, Universidad Nacional de Colombia, Bogotá, Colombia (ICN-Ar, E. Flórez) and in the Instituto Butantan, São Paulo, Brazil (IBSP, A. D. Brescovit). 
One male specimen of $A$. polli (R. Jocqué, 1991 det.), from Hato, $12^{\circ} 11^{\prime} 20^{\prime}$ 'N 68 $57^{\circ} 35^{\prime}$ 'W, Willsmtad, Curaçao, 20-23 Feb. 1960, B. Malkin col., deposited in the collection of the American Museum of Natural History, number 00326278 , was used for comparison.

\section{Antillorena sanjacintensis sp. nov.}

(Figs 1-11, 14-17)

urn:lsid:zoobank.org:pub:805A52F4-24E6-47A4-9D268851B462892D

Type material. Male holotype from Vereda La Flecha, 951'26.61”N, 75¹0’48.46”W, 470-520 m, San Jacinto, Bolívar, Colombia, IX. 2014, L. Quijano col. (ICN-Ar 8229). Paratypes: $3 ð$ from the same locality of holotype (2ð ICN-Ar 8231; $\precsim$ IBSP 168379) and 9 (ICN-Ar8230) and $3 \widehat{\partial}(2 \hat{\jmath}$ ICN-Ar 8232; $\widehat{\jmath}$ IBSP 168740) from Reserva Campesina La Montaña, 1046’02.6”N, $75^{\circ} 02^{\prime} 34^{\prime \prime} \mathrm{W}, 160-250 \mathrm{~m}$, Usiacurí, Atlántico, Colombia, III.2016, L. Martinez col.

Other material examined. One subadult male, two subadult female and one juvenile from the same locality of holotype (ICN-Ar 8231).

Etymology. The specific name refer to toponym San Jacinto, one of the municipality where the type specimens were collected.

Diagnosis. Males of $A$. sanjacintensis sp. nov. are similar to those of $A$. polli (see Figs 12,13; JoCQUÉ, 1991:35, figs $48-51,94)$ by the simple ventral tibial apophysis, the origin and shape of the cymbium basal projection and by the size, direction and shape of the median apophysis. However, can be distinguished by having the retrolateral tibial apophysis with the distal area shorter and acuminate at the tip, narrower and longer proximal tegular apophysis and by the shorter and bent conductor than in $A$. polli (Figs $3-5 ; 8,9 ; 14-17)$. The females resemble those of the $A$. polli by the long folding of the ducts with more than seven turns, but differs by the pore of the atrium at the posterior border of the median septum (Figs 6, 10) and by presenting eight turns of the ducts (Figs 7, 11).

Description. Male (holotype, ICN-Ar 8229). Total length 7.46. Carapace 3.92 long, 2.65 wide. Carapace pear-shaped, dark brown, highest at the fovea region and clearer. Labium triangular, brown. Endites orange-brown, with white apex. Chelicerae and sternum brown. Legs orange-brown, except the femora with green-brown color. Abdomen dark grey dorsally with a pattern of white spots on the median area arriving just before of the spinnerets, ventrally white with black lines in the lateral and medial areas. Spinnerets orange (Fig. 1). Eye sizes and interdistances: PLE $>$ PME $>$ ALE $>$ AME; AME: 0.114, ALE: 0.125, PME: 0.130, PLE: 0.134, AME-AME: 0.04, AME-ALE: 0.10, PME-PME: 0.07, PME-PLE: 0.18, ALE-PLE: 0.05, MOQ: 0.27 anterior width, 0.33 posterior width, 0.30 long. Leg formula: 4123. Leg measurements: I femur 2.46/ patella 1.29/ tibia $1.97 /$ metatarsus 1.88 / tarsus $0.90 /$ total 8.52 ; II $2.24 /$ 1.26/ 1.57/ 1.72/ 0.92/ 7.74; III 1.97/ 1.09/0.92/ 1.79/ 0.84/
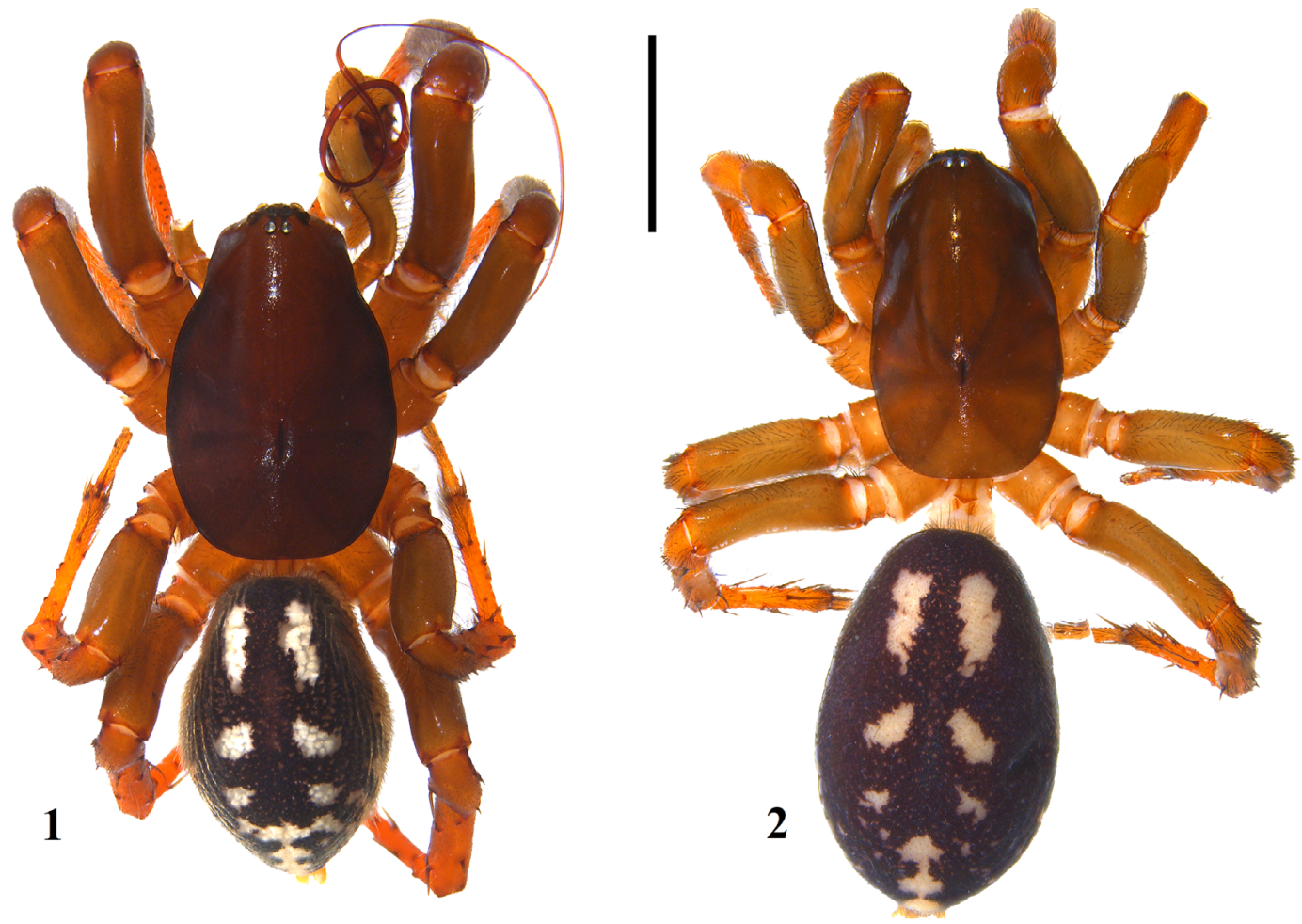

Figs 1, 2. Antillorena sanjacintensis sp. nov.: 1, male (holotype, ICN-Ar 8229), dorsal view; 2 , female (paratype, ICN-Ar8230), dorsal view. Scale: 2 mm. 

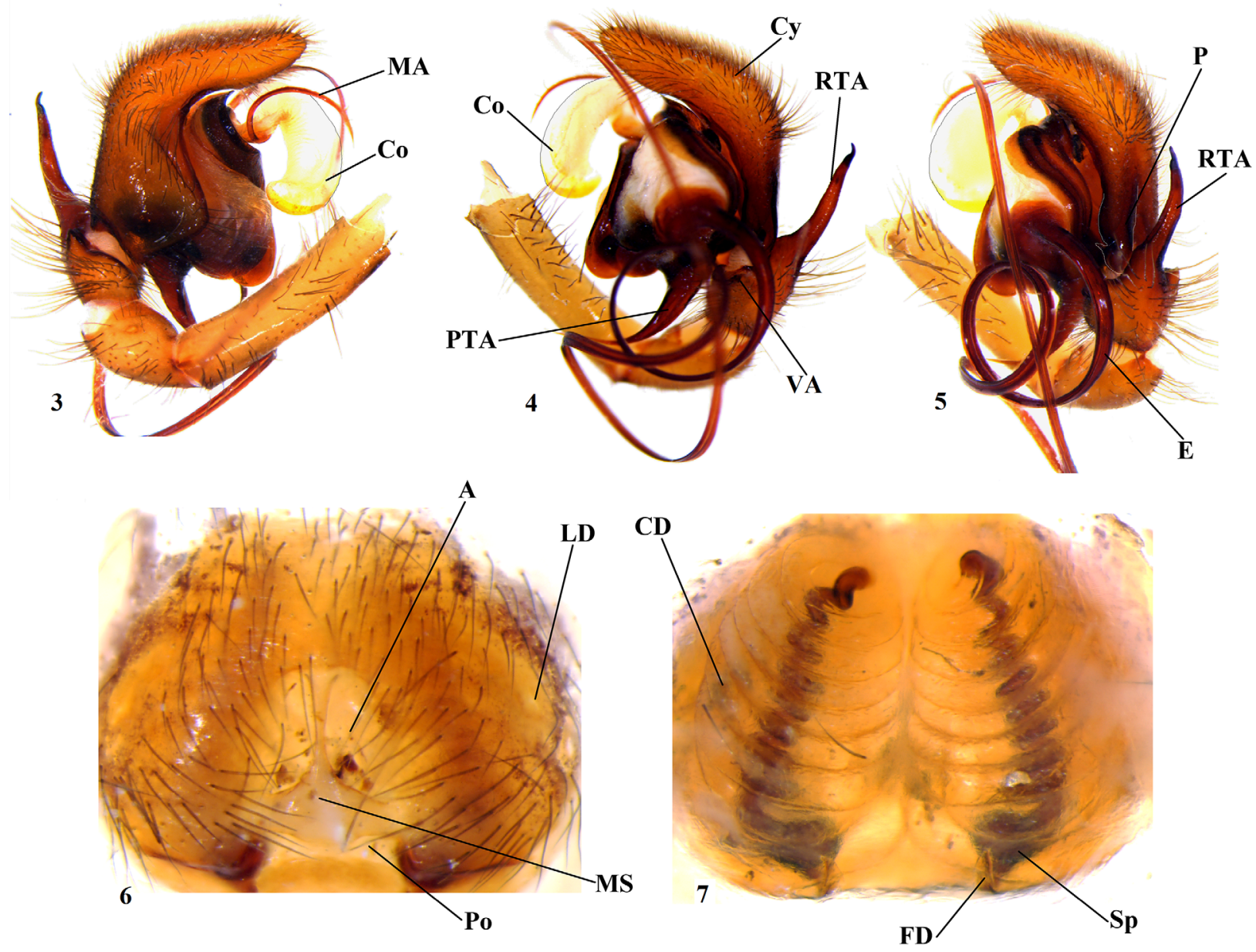

Figs 3-7. Antillorena sanjacintensis sp. nov., male palp (holotype, ICN-Ar 8229): 3, prolateral view; 4. retrolateral view, 5. retrodorsal view. Female (paratype, ICN-Ar 8230): 6, Epyginum, ventral view; 7, vulva, dorsal view (A, atrium; Co, conductor; Cy, cymbium; E, embolus; FD, fertilization ducts; LD, lateral depression; MA, median apophysis; MS, median septum; P, cymbial retrolateral projection; Po, pocket; PTA, proximal tegular apophysis; RTA, retrolateral tibial apophysis; VA, ventral tibial apophysis. Scale: palp $(0.5 \mathrm{~mm})$; epyginum and vulva $(0.2 \mathrm{~mm})$.

6.64; IV 2.35/ 1.25/ 1.55/ 2.64/ 0.95/ 8.76. Leg spination: III patella d0-0-1, p0-1-0, r0-1-1, v0; tibia d1-1-0, p0-1-1, r1-1-1, v2-2-2; metatarsus d1-2-2, p0-0-1, r1-1-1, v2-2-2; tarsus $\mathrm{d} 0$, p0, r0, v0-1-2. IV patella d0-0-1, p0-1-0, r0-1-1, v0; tibia d1-1-0, p0-1-1, r1-1-1, v2-2-2; metatarsus d1-22, p0-0-1, r1-1-1, v2-2-2; tarsus r0-0-1. Palp: retrolateral tibial apophysis long with a curved tip. Cymbium with a retrolatero-basal projection. Tegulum with a long and curved proximal tegular apophysis and a ventral tegular apophysis; median apophysis long and curved, with base covered by tegulum; hyaline and voluminous apical conductor, embolus S-shaped extremely long, originating from retrolateral side (Figs 3-5; 8, 9; 14-17).

Female (Paratype, ICN-Ar 8230). Total length 8.36. Carapace 3.53 long, 2.16 wide. Carapace pear-shaped, brown, less intense than in the male, highest at the fovea region. Labium triangular, brown. Endites light brown with white apex. Chelicerae and sternum brown. Legs and abdomen as in male (Fig. 2). Eye sizes and interdistances: PLE $>$ PME $>$ ALE $>$ AME; AME: 0.107, ALE: 0.123, PME:
0.127, PLE: 0.135, AME-AME: 0.028, AME-ALE: 0.109, PME-PME: 0.059, PME-PLE: 0.152, ALE-PLE: 0.042, MOQ: 0.226 anterior width, 0.309 posterior width, 0.292 long. Leg formula: 4123. Leg measurements: I femur 1.75/ patella 1.11 / tibia 1.53 / metatarsus 1.23 / tarsus 0.81 / total 6.45; II $1.81 / 0.97 / 1.26 / 1.29 / 0.82 /$ total 6.18 ; III $1.59 /$ $0.82 / 0.89 / 1.35 / 0.79 /$ total $5.45 ;$ IV $2.01 / 0.97 / 1.38 / 1.91 /$ $0.87 /$ total 7.16. Leg spination: I metatarsus $\mathrm{d} 0, \mathrm{p} 0, \mathrm{r} 0$, v22-2 II tibia d0, p0, r0, v0-2-0; metatarsus d0, p0, r0, v2-2-2, III patella d0-0-1, p0-1-0, r1-1-0; v0; tibia d1-1-0, p0-1-1, r1-1-1, v2-1-2; metatarsus d2-2-2, p0-0-1, r0-0-1, v2-1-2; tarsus d0, p0, r-0-1-0, v0-1-2; IV patella d0-0-1, p0-1-0, r1-1-0, v0; tibia d1-1-0, p0-1-1, r1-1-1, v2-2-2; metatarsus $\mathrm{d} 2-2-2, \mathrm{p} 0-1-0, \mathrm{r} 0-1-1, \mathrm{v} 2-2-2$; tarsus $\mathrm{d} 0, \mathrm{p} 0-1-0, \mathrm{r} 0, \mathrm{v} 0-1-2$. Epigynum with shallow lateral depressions, atrium oval, median septum triangular with two large pockets (Figs $6,10)$; internally, long copulatory ducts, basal rounded spermathecae and long fertilization ducts in the base of spermathecae (Figs 7, 11).

Variation. Length (7 males): total: 6.46-7.98; carapace: 3.48-4.15; femur I: 2.53-2.93. 

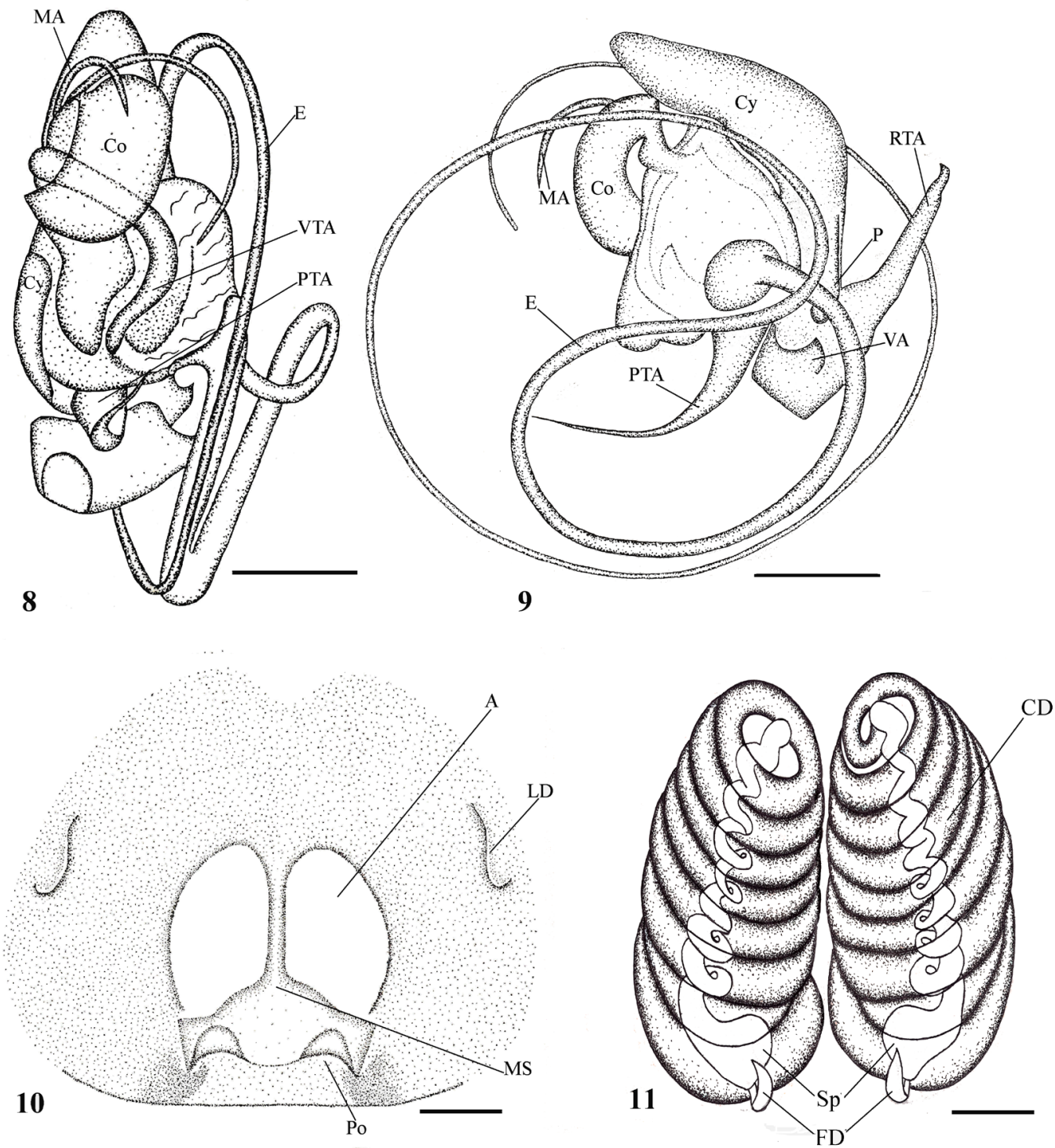

Figs 8-11. Antillorena sanjacintensis sp. nov., male palp (holotype, ICN-Ar 8229): 8, ventral view; 9, retrolateral view. Female (Paratype, ICN-Ar 8230): 10, Epyginum, ventral view; 11, vulva, dorsal view (A, atrium; Co, conductor; Cy, cymbium; E, embolus; FD, fertilization ducts; LD, lateral depression; MA, median apophysis; MS, median septum; P, cymbial retrolateral projection; Po, pocket; PTA, proximal tegular apophysis; RTA, retrolateral tibial apophysis; VA, ventral tibial apophysis, VTA, ventral tegular apophysis. Scale: palp $(0.5 \mathrm{~mm})$; epyginum and vulva $(0.2 \mathrm{~mm})$.

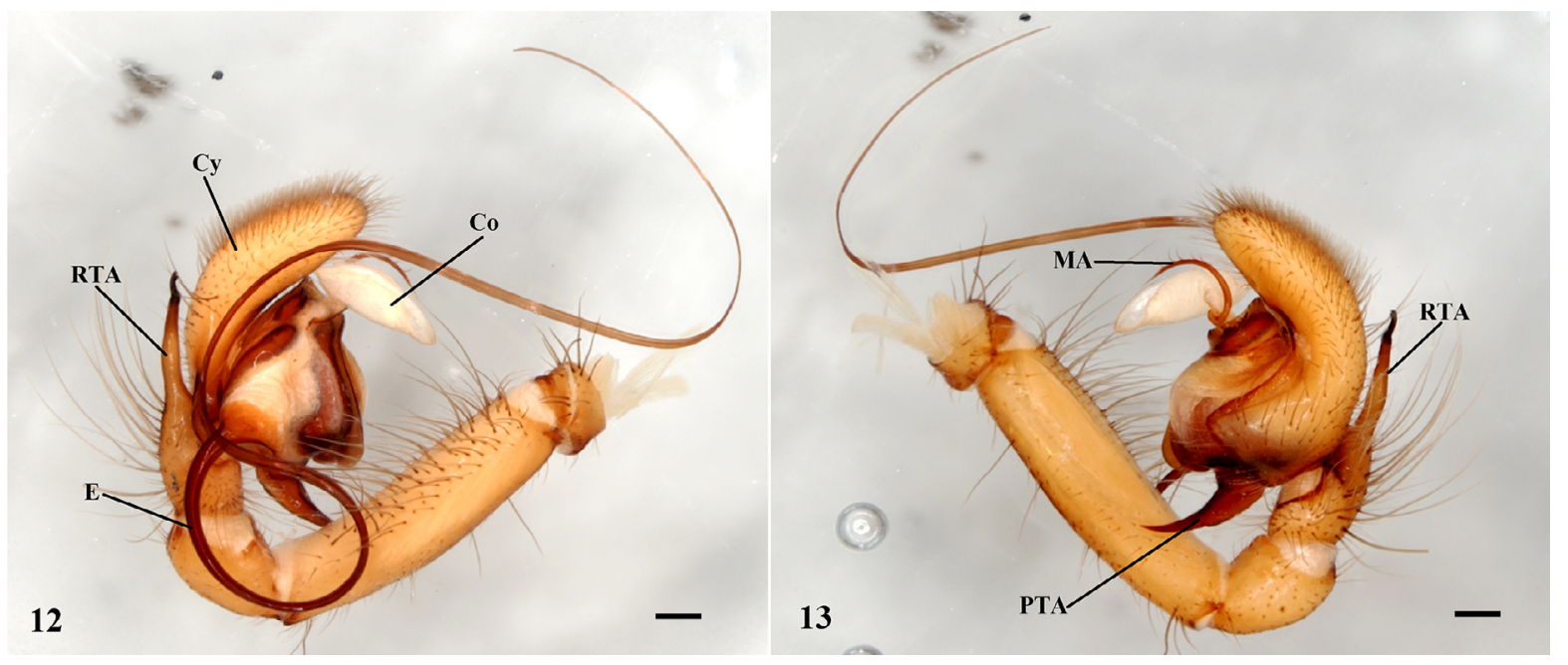

Figs 12, 13. Antillorena polli (Simon, 1887), male palp (AMNH 00326278): 6, retrolateral view; 7, prolateral view (Co, conductor; Cy, cymbium; E, embolus; MA, median apophysis; PTA, proximal tegular apophysis; RTA, retrolateral tibial apophysis). Scale: palp (0.5mm). 

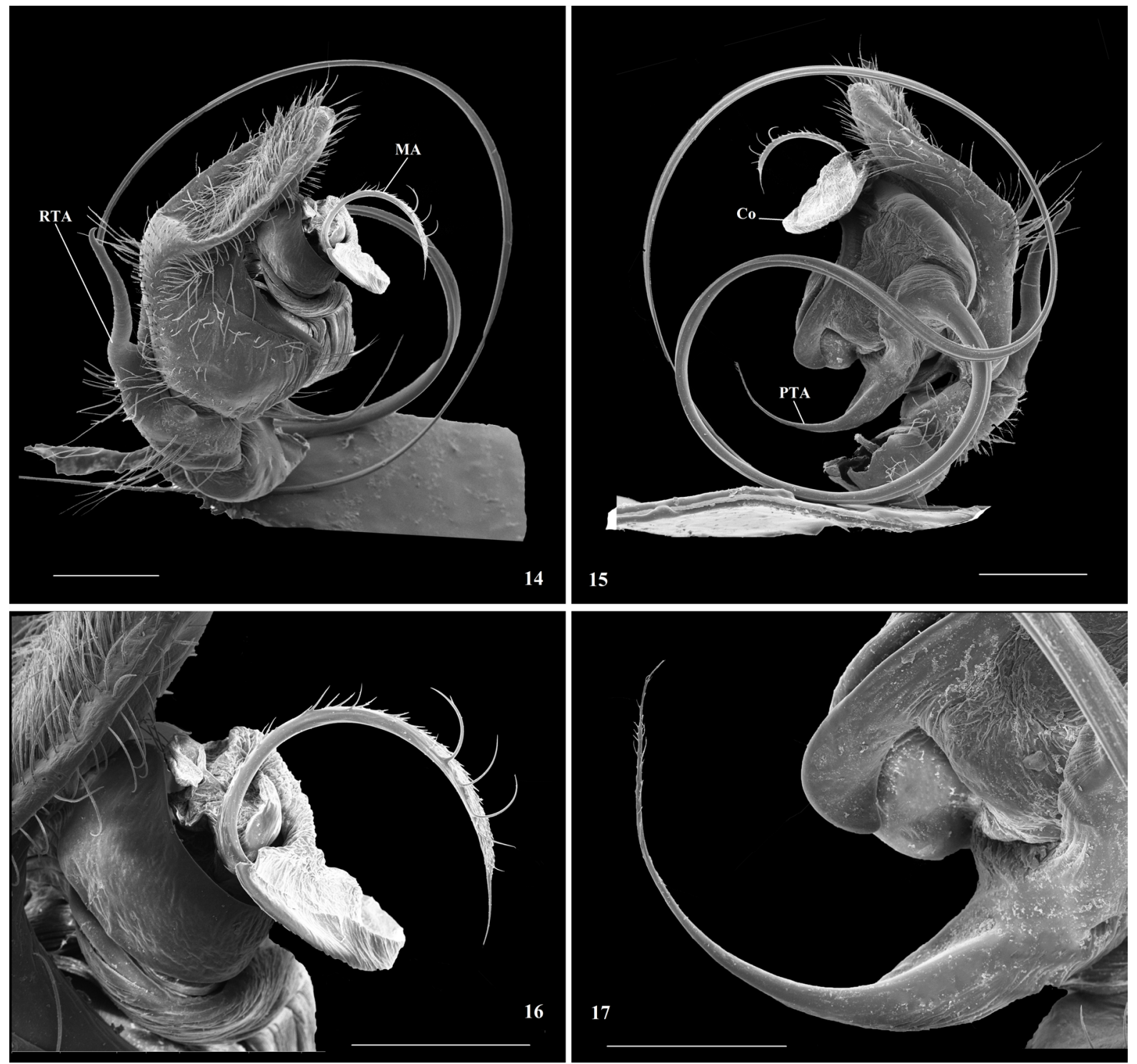

Figs 14-17. Antillorena sanjacintensis sp. nov., male palp (ICN-Ar 8231): 14, prolateral view; 15, retrolateral view; 16, median apophysis and conductor, prolateral view; 17, proximal tegular apophysis, retrolateral view. Scales: 14, $15(0.5 \mathrm{~mm}), 16,17(0.3 \mathrm{~mm})$.

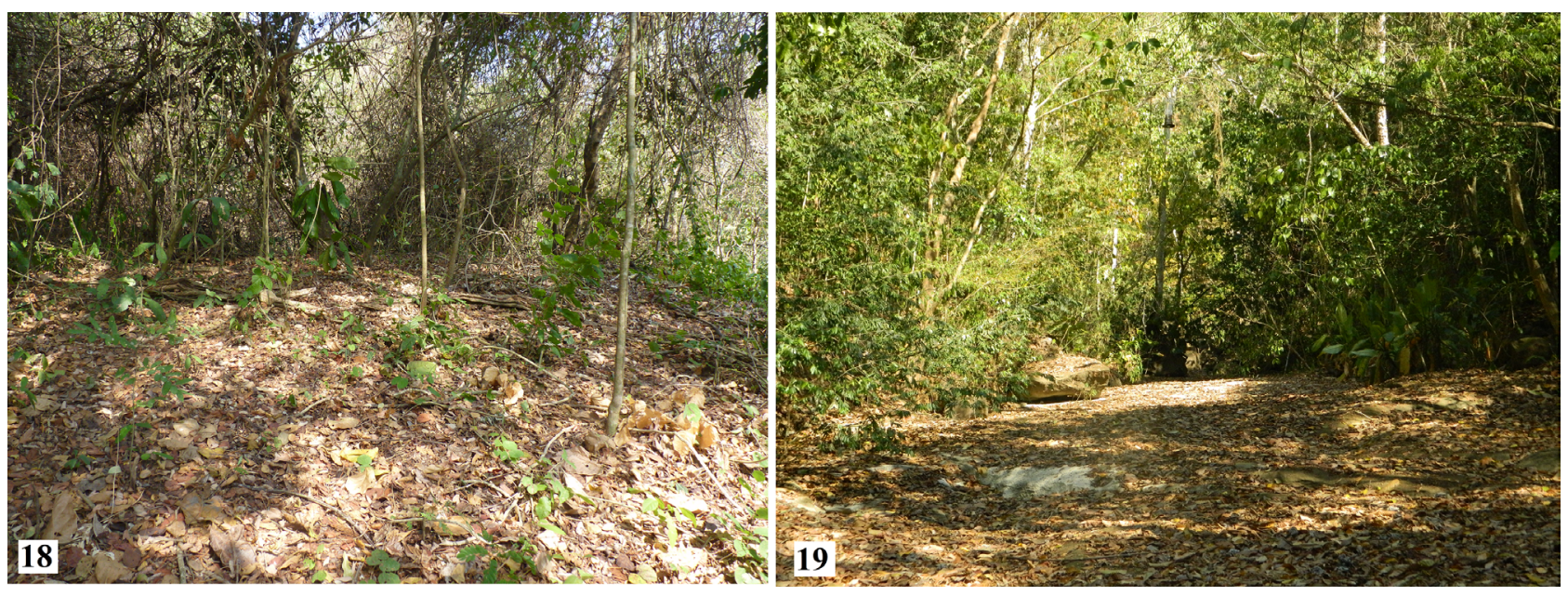

Figs 18, 19. Landscape where Antillorena sanjacintensis sp. nov. was found in Colombia: 18, Reserva Campesina La Montaña (Usiacurí); 19, Vereda La Flecha (Bolívar). 


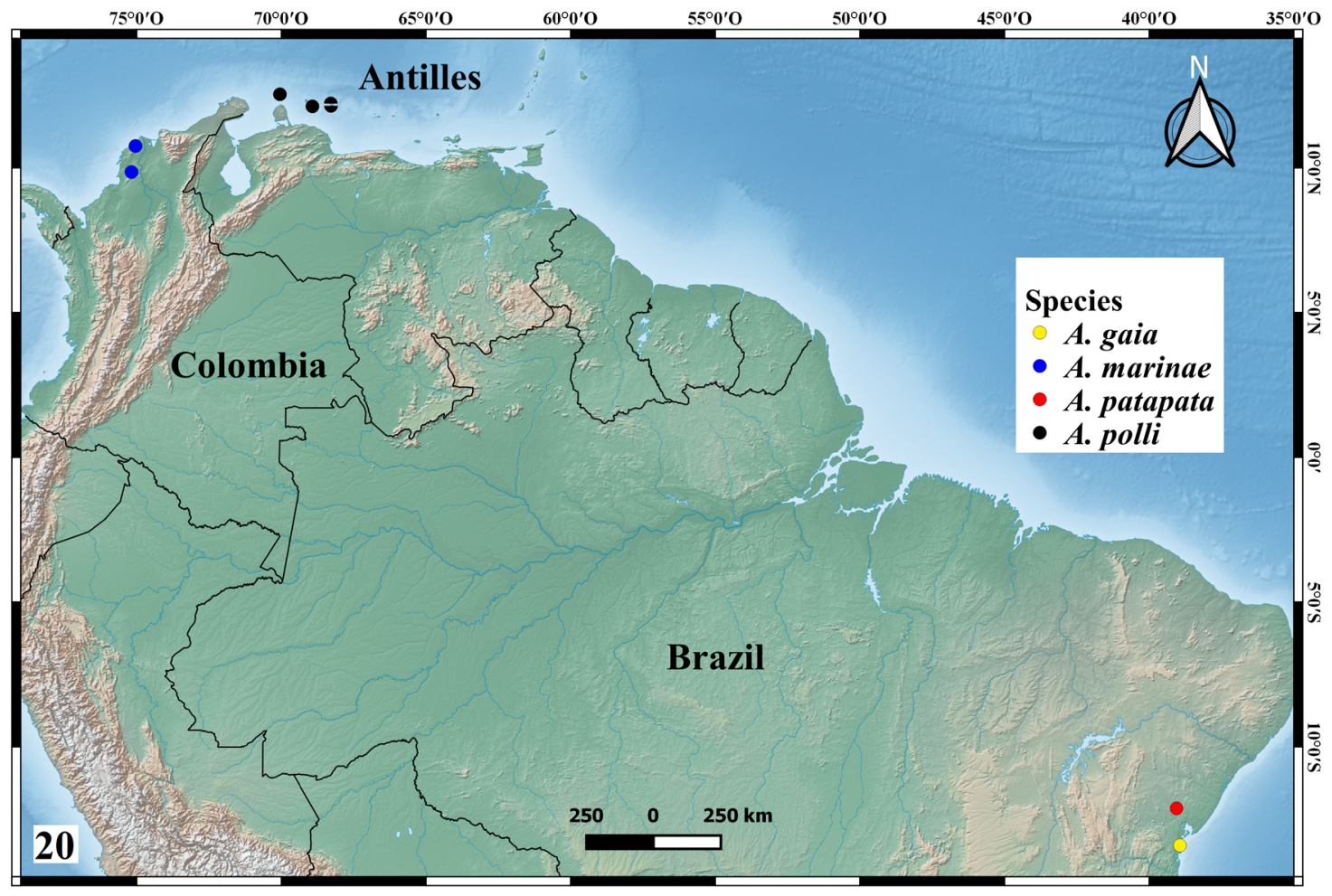

Fig. 20. Distribution records of the genus Antillorena in South America and the Lesser Antilles.

Natural history. The specimens of $A$. sanjacintensis sp. nov. were found in leaf litter, open trail and near of low grasslands, in a landscape with dry tropical forest in the northern from Colombia (Figs 18, 19).

Distribution. Atlántico and Bolívar departments, Colombia (Fig. 20).

\section{Key to species of Antillorena}

1. Female. 2

Male. 5

2. Epigynal plate with broad median septum and globose pockets, internally, copulatory ducts with three coils (BRESCOVIT \& RUIZ, 2011: fig. 9) A.patapata Epigynal plate with triangular median septum and elongate pockets, internally, copulatory ducts with more than three coils (Figs 10,11; BresCOVIT \& RuIZ, 2011:fig. 15) ........ 3

3. Copulatory ducts with four coils (Brescovit \& Ruiz, 2011:fig. 16) ....................................................... gaia Copulatory ducts with more than five coils (Fig. 11) ....... 4

4. Copulatory ducts with eight coils, oval atrium, medium septum with large pockets (Fig. 11)

sanjacintensis $\mathrm{sp}$. nov. Copulatory ducts with seven coils, lung-shaped atrium, medium septum with straight pockets (JOCQUÉ, 1991:fig. 51). A. polli

5. RTA short and straight, with less than half the length of the cymbium (Brescovit \& RuIz, 2011:fig. 8)

A. patapata
RTA elongate, with almost half the length of the cymbium (Figs 3-5, 9, 14, 15; BRESCOVIT \& RuIZ, 2011:fig. 14)

6. RTA with bifid distal tip, short PTA with enlarged base (JoCQUÉ, 1991:fig. 48) A.polli RTA with acuminate distal tip, long PTA with straight base (Figs 3-5; 9; 14, 15; Brescovit \& RuIZ, 2011:fig. 14)

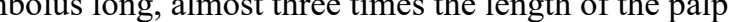
cymbium without dorsal depression, conductor with conspicuous base and not covered by the tegulum, sinuous RTA(Figs 3-5, 8,9, 14, 15) ....... A. sanjacintensis sp. nov. Embolus short, almost two times the length of the palp; cymbium with dorsal depression, conductor without conspicuous base and covered by the tegulum, straight RTA (BRESCOVIT \& RuIZ, 2011:figs 13, 14) ............. A. gaia

Acknowledgements. We are grateful to Franklyn Cala, A. B. Bonaldo, D. Candiani and Eduardo Flórez for comments and suggestions on an early version of this manuscript; to Leonel Martínez for sharing the pictures obtained through scanning electron microscopy, to the Universidad del Atlántico and the Instituto de Ciencias Naturales of the Universidad Nacional de Colombia for their logistics support. Finally, to L. Prendini and L. Sorkin (AMNH) by the loan of specimens of A. polli and V. Passanha by the pictures of the male palp. This study was supported by CNPq301776/2004-0 grant to ADB.

\section{REFERENCES}

Brescovit, A. \& RuIz, G. 2011. Two new species of Antillorena Jocqué, 1991 from northeastern Brazil (Araneae, Zodariidae). Zootaxa 2973:57-65. GerTSCH, W. J. 1961. The spider genus Lutica. Senckenbergiana Biologica 42:365-374. 
Hasselt, A. W. M. van. 1887. Araneae exoticae quas collegit pro Museo Lugdunensi, J. R. H. Neervoort van de Poll, insulis Curaçao, Bonaire et Arubâ. Tijdschrift voor Entomologie 30:227-244.

JoCQUÉ, R. 1991. A generic revision of the spider family Zodariidae (Araneae). Bulletin of the American Museum of Natural History 201:1-160.
Petrunkevitch, A. 1925. Arachnida from Panama. Transactions of the Connecticut Academy of Arts and Sciences 27:51-248.

World SPIDER Catalog. 2018. Natural History Museum Bern. Avaliable at $<$ http://wsc.nmbe.ch, version 19.0 $>$. Accessed on 20 September 2018. doi: $10.24436 / 2$ 